\title{
Transition of a major tailings facility in a sensitive environment — from operation to decommissioning at Brenda Mine
}

\author{
R.C. Lo Klohn Crippen Berger Ltd, Canada \\ J. Stroiazzo Xstrata Copper, Canada \\ G. Guilleminot Xstrata Copper, Canada
}

\begin{abstract}
The Brenda Mine closure plan had been developed in consultation with regulators and stakeholders. Reclamation work at the mine was carried out whenever practical, while the mine was still in operation prior to 1990. Additional reclamation work continues to date. The molybdenum-related geochemical issue played a dominant role in the adopted closure scheme. To mitigate the impact of mine-site molybdenumbearing water on the quality of water in the surrounding environment, a water treatment plant, with a maximum installed treatment capacity of $313 \mathrm{l} / \mathrm{s}$ was constructed. With the plant starting operation in 1998, excess molybdenum-bearing water stored in the tailings pond and pit lake, has been treated in the plant and released on a scheduled annual basis under permit. Ongoing monitoring of surface and groundwater quality at control locations has been carried out to confirm compliance of permit conditions. This paper describes how site water management has become the key to successful decommissioning at Brenda Mine. It covers all man-made landforms within the mine proper related to water management need. Moreover, the long-term dam safety aspect of the two key tailings dams are discussed in light of their design and construction history.
\end{abstract}

\section{Introduction}

Brenda Mine is located in south central British Columbia, Canada (Figure 1a). Its tailings impoundment, retained by two tailings dams (Figure 1b), is located in a relatively narrow MacDonald Creek valley with a steep gradient at the headwaters of a small stream, Trepanier Creek. The stream flows into Okanagan Lake, a major regional fruit and wine producing tourist and recreational area. Both Trepanier and Peachland Creeks adjacent to the mine are fish-bearing tributaries. The area of the former catchment is about 26,000 ha and the latter area is about 14,000 ha. There is $543 \mathrm{~km}$ of roads within the two catchments, including the divided, four-lane Coquihalla Highway skirting near the toe of the main tailings dam. Both catchments are under forest licenses.

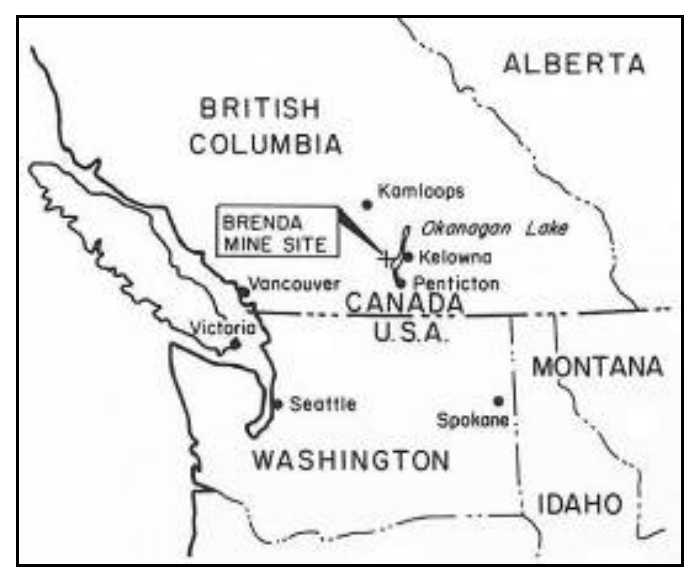

(a)

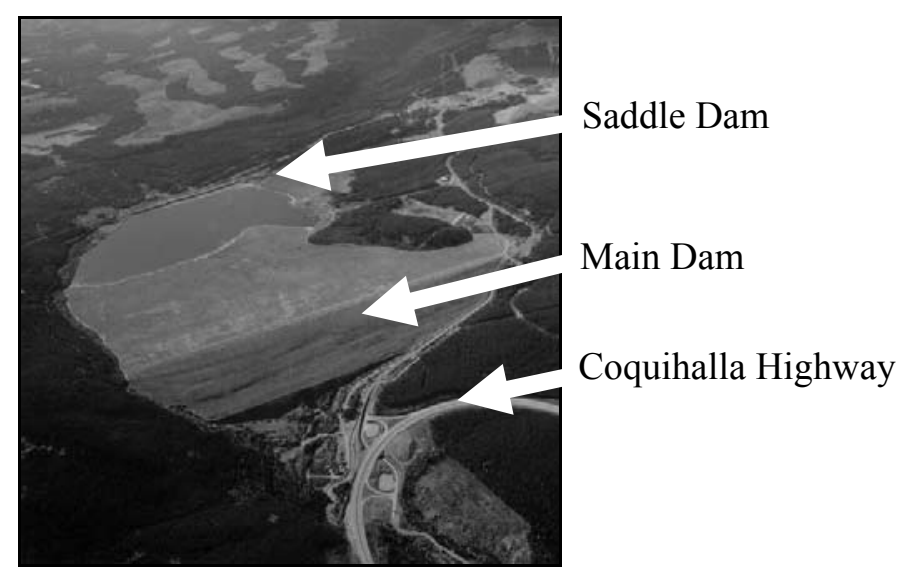

(b)

Figure 1 (a) Location plan of Brenda Mine (Klohn, 1984); and (b) Brenda Mine tailings impoundment 


\subsection{Mining history and current status}

The Brenda Mine, a subsidiary of Noranda Mine, was a low-grade molybdenum-copper open pit operation with a daily throughput of 29,000 t per day from 1969 to 1990 . The construction of the main dam was completed to a nominal crest elevation of 1,392.9 $\mathrm{m}$ in June 1986, while the saddle dam was completed to the same crest elevation in September 1989. Since the cessation of mining operation, the mine is under care and maintenance in a transition period towards eventual decommissioning.

Due to acquisition activities in the mining industry, Brenda Mine has gone through two changes of ownership: from Noranda Mine to Falconbridge to Xstrata Copper. However, ongoing site activities continue seamlessly, according to the Brenda Mine Operation, Maintenance and Surveillance Manual, which was developed following the guidelines of Canadian Dam Association and Mining Association of Canada. The manual also details emergency response procedures and incident notification protocols to regulators, emergency responders and the public. The continuous smooth site operation attests the due-diligence measures taken by all the mining companies involved.

\subsection{Site condition}

The mine site is moderately seismic with a maximum considered earthquake of magnitude 6.5 along the inferred Okanagan Valley branch of the Louis Creek Fault located $18 \mathrm{~km}$ away. Total annual precipitation is in the order of $550 \mathrm{~mm}, 60 \%$ of which is in the form of snowfall from November to April. The spring runoff due to snowmelt contributes about $80 \%$ of the total runoff. Mean daily temperatures vary from $-10^{\circ} \mathrm{C}$ in January to $+22^{\circ} \mathrm{C}$ in July. The Brenda Mine is located within the Brenda Stock, part of Pennask Batholith. Faults in the open pit area are expressed as fracture zones in which the rock is intensely fractured to clay minerals, sericite, epidote and chlorite. The faults transect all mineralisation with sulphides, especially molybdenite, smeared along fault planes. The natural slopes surrounding the site are covered by glacial deposits of variable thickness.

\subsection{Key decommissioning problem}

The key decommissioning problem at Brenda Mine is finding a satisfactory closure solution for molybdenum-bearing site drainage (SRK et al., 1993). Outlined below is the development of this drainage issue related to the following permanent man-made landforms:

- Waste rock piles and low-grade ore piles - molybdenum leaching process from the waste rock and low-grade ore piles appears to be constrained by chemical control and transport control due to channelisation of flow through rock piles (SRK, 1992). During mining operation, this molybdenumbearing drainage was collected within the tailings pond to be separated from the environment.

- Tailings storage facility - in addition, waste rock and cycloned tailings sand used for constructing tailings dams as well as stored tailings also contributed to a lesser extent to molybdenum content of tailings pond water.

- Pit lake - after cessation of mining, the open pit was gradually in-filled by groundwater recovery, local site drainage and water transferred from the tailings impoundment.

Sections 3 and 4 describe the evolution of a site drainage management plan (Stanley, 1995; Agra, 1998a), and water treatment operation that have been adopted with extensive public, government, and NGO consultation and participation. Long-term multiple land and water uses considered human, fruit, cattle, and aquatic life. Evaluations were conducted on vegetation, cattle and wildlife monitoring and water quality of discharge and receiving environment. The process was guided by Brenda Mine Public Surveillance Committee and Technical Working Committee. The Public Surveillance Committee was chaired by the B.C. Ministry of Energy, Mines and Petroleum Resources, and the Technical Working Group incorporated technical input by the British Columbia Provincial Government.

\section{Tailings facility}

The tailings facility consists of a $2 \mathrm{~km}$ long, $137 \mathrm{~m}$ high main dam (Figure 2) at the downstream end in the Trepanier Creek catchment and a $950 \mathrm{~m}$ long, $38 \mathrm{~m}$ high earth and rockfill saddle dam at the upstream end in 
the Peachland Creek catchment. The $1.7 \mathrm{~km}$ long and $1.5 \mathrm{~km}$ wide tailings impoundment has an area of 370 ha, a water storage capacity of 6 million $\mathrm{m}^{3}$, and a catchment area of 1,810 ha. It stores about $230 \mathrm{Mt}$ of mine tailings generated from the past mining operation. Seepage through the tailings dams are stored in the lower and upper reclaim ponds and pumped back into the tailings pond.

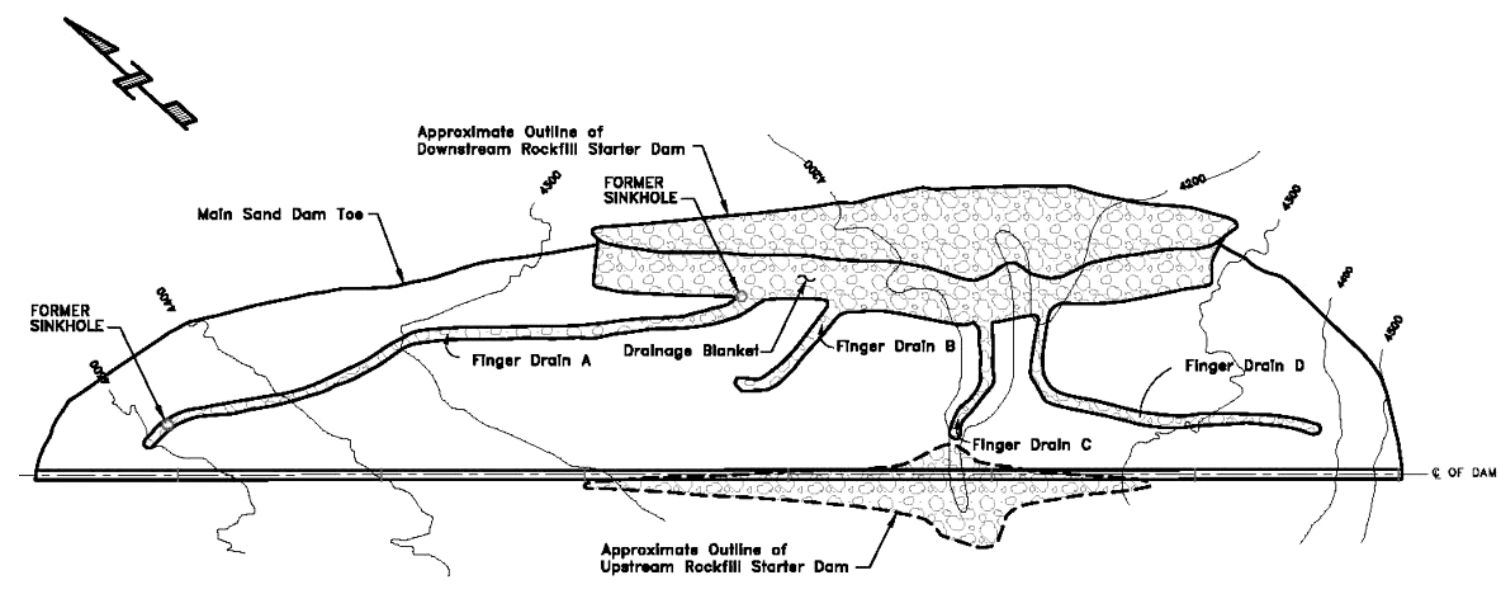

PLAN VIEW

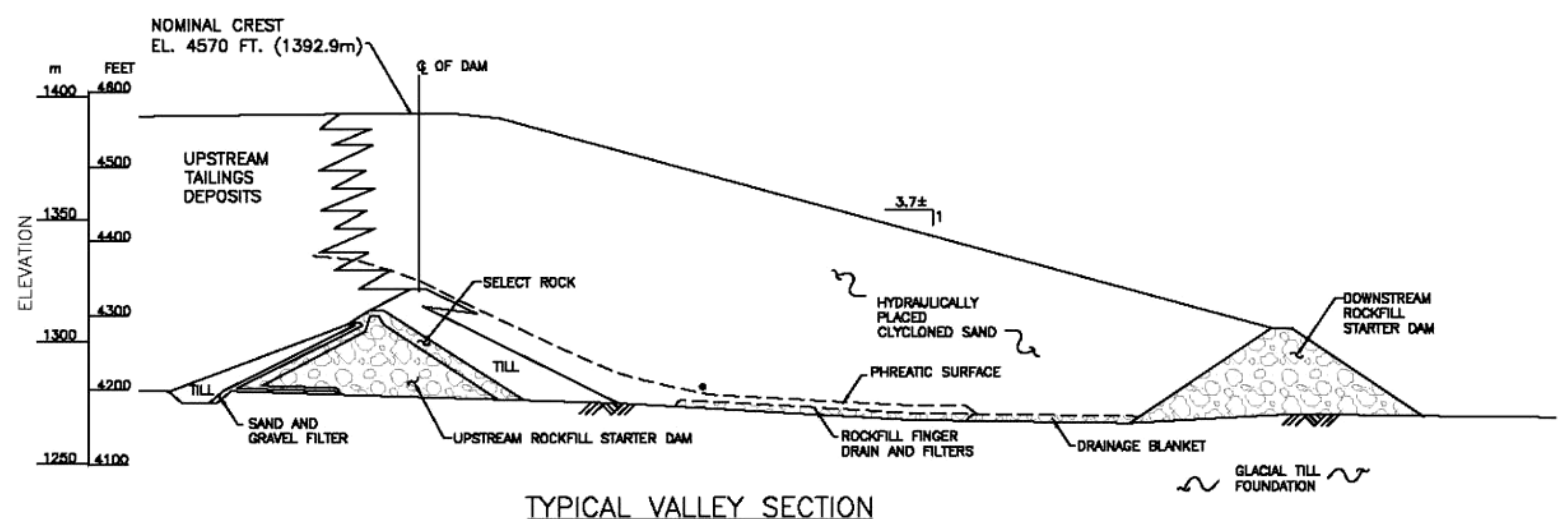

Figure 2 Main dam - plan view (top) and typical valley section (bottom)

\subsection{Main dam}

The main dam adopted the following three design features to achieve the required seismic resistance at a reasonable construction cost:

- Flat downstream dam slope.

- Medium-dense sand damfill.

- Low phreatic surface.

Figure 2 shows the plan view of various internal drainage features and the typical valley dam section. To implement the above design features, the following measures were taken:

- Construct medium-dense damfill of clean, free-draining, double-cycloned tailings sandfill by means of hydraulic fill construction using a cyclone station located at the north abutment.

- Maintain a wide tailings beach to form an impervious seepage barrier upstream of the dam.

- Construct internal finger drains and toe drainage blanket to lower the phreatic surface.

- Construct an earth and rockfill upstream starter dam along the dam centreline, and raise the dam by the centreline method.

- Construct a downstream rockfill starter dam across a narrow, steep valley at the toe to provide a freedraining buttress. 
The dam construction was managed and monitored by mine personnel with regular site reviews by its designers. Construction issues requiring special attention included:

- Maintaining sufficient freeboard during spring runoffs and prolonged shut down due to low metal prices.

- Adjusting construction procedures to prevent temporarily elevated piezometric surface in localised areas where prolonged hydraulic fill operation occurred.

- Repairing two sinkholes formed in areas where filter deficiency occurred locally at Finger Drain A.

Extensive field and laboratory investigations were carried out in 1980-1983 to acquire basic data and static and dynamic soil properties of the damfill for comprehensive seismic response analyses of the sandfill dam (Klohn, 1984). The analyses confirmed that the as-built dam will withstand the design earthquake and maintain its integrity.

The downstream slope of the sandfill of the completed dam is about $3.7 \mathrm{H}: 1 \mathrm{~V}$. The cycloned sandfill is a fine to medium sand with a fines content ranging from 5 to $10 \%$ passing through No. 200 mesh sieve. The $\left(\mathrm{N}_{1}\right)_{60}$ blow counts of the sandfill are in the range of 12 to 16 down to a depth of $75 \mathrm{~m}$, indicating the mediumdense state. The dam was completed in 1990 and successfully reclaimed in 1990s (Figures 3 and 4a).

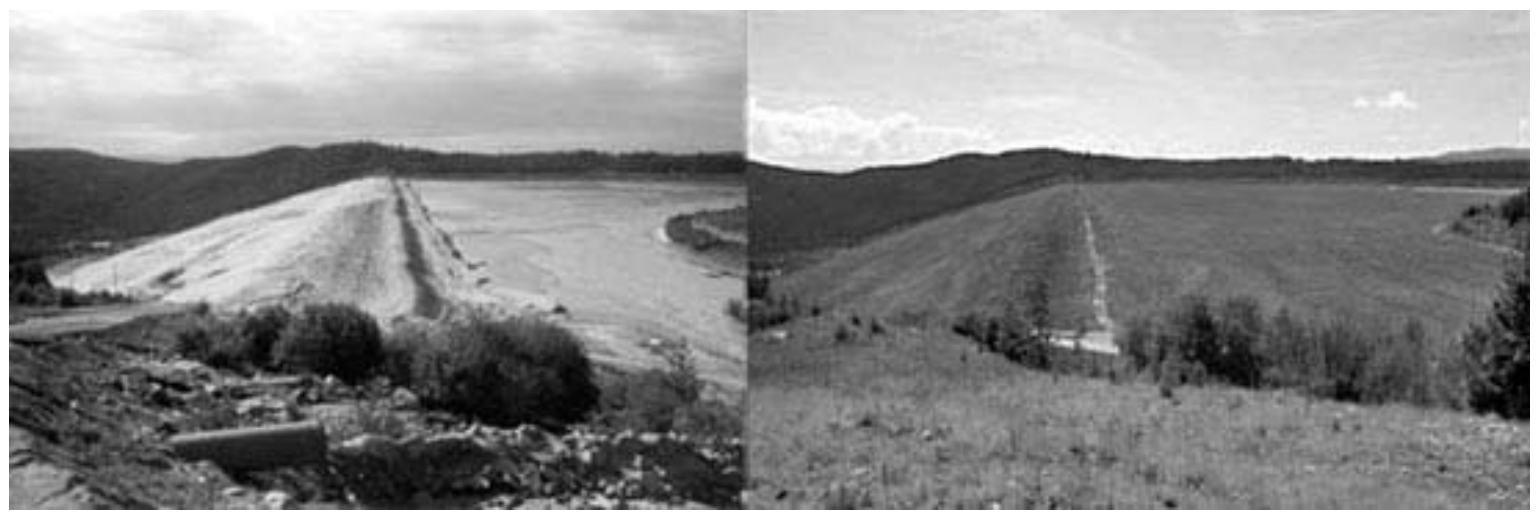

Figure 3 Brenda Mine main dam: upstream tailings beach, dam crest and downstream slope before and after reclamation

\subsection{Saddle dam}

The saddle dam is a compacted earth and rock fill dam with a central glacial till core for retention of water and tailings. It is more erosion resistant than the main dam. Its downstream shell has a low phreatic surface, ensuring high seismic resistance of the dam. The saddle dam was constructed in stages from 1979 to 1989.

In 1999, an emergency discharge facility was constructed at the saddle dam to safeguard the main dam from overtopping. The discharge facility, designed by Agra (1999), consists of a $30 \mathrm{~m}$ wide free overflow segment of the saddle dam with the crest lowered by $2.4 \mathrm{~m}$ from the rest of the dam and two $900 \mathrm{~mm}$ diameter corrugated steel pipe culverts with the invert at El. 1,387 m (Figure 4b). Since 1999, the tailings pond level has been maintained within a $2.3 \mathrm{~m}$ range with a minimum freeboard of $1.9 \mathrm{~m}$ below the invert of the two discharge culverts, and a minimum freeboard of $7.8 \mathrm{~m}$ below the crest of the main dam. 


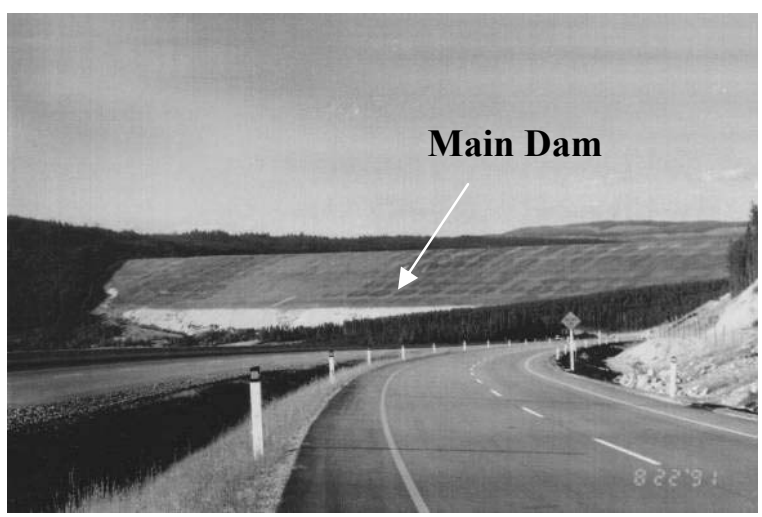

(a)

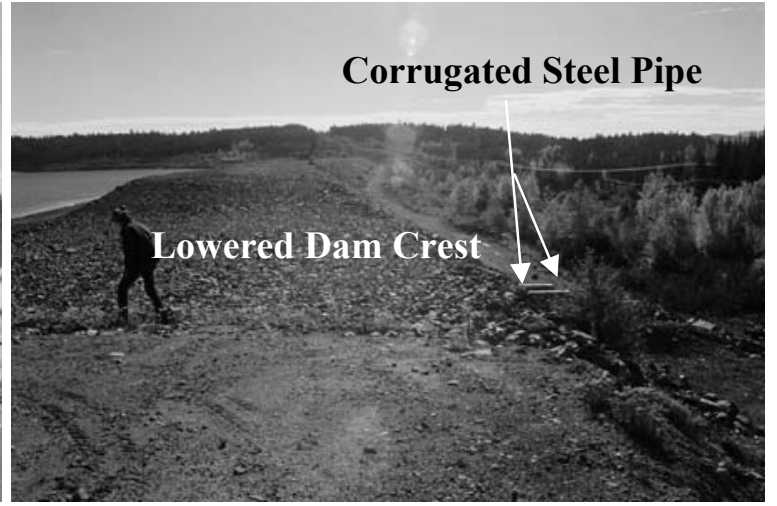

(b)

Figure 4 (a) Downstream face of main dam - viewed from Coquihalla Highway; and (b) saddle dam with emergency discharge culverts and lowered dam crest

\section{Site drainage management plan}

Site runoff water has been managed in separate streams: with clean (non-molybdenum bearing) water being diverted to the downstream Trepanier and Peachland Creeks, while contaminated (molybdenum bearing) water being stored in the tailings pond during mining operation, and later also in the pit lake after 1990.

As the pit lake was being filled, Brenda implemented a runoff management scheme involving treat and release of excess mine site molybdenum-bearing water under permit to mitigate the impact on the quality of water in the surrounding environment. Agra (1998a) performed a site water balance simulation using appropriate meteorological and hydrological data as a basis for the design of the Brenda site long-term runoff management scheme as illustrated in Figure 5. This scheme is for the current molybdenum-bearing water collect and treat phase, which is expected to last for a period of 150 to 200 years. After this transition period, it is expected that the water quality within the tailings pond and pit lake will improve with time due to influx of precipitation, outflow of treated water and gradually decreasing leaching activity. At that time excess water from these two sources could then be safely released to the environment without further treatment. To date no statistically significant changes have been observed in the water quality data for the tailings pond and pit lake. 


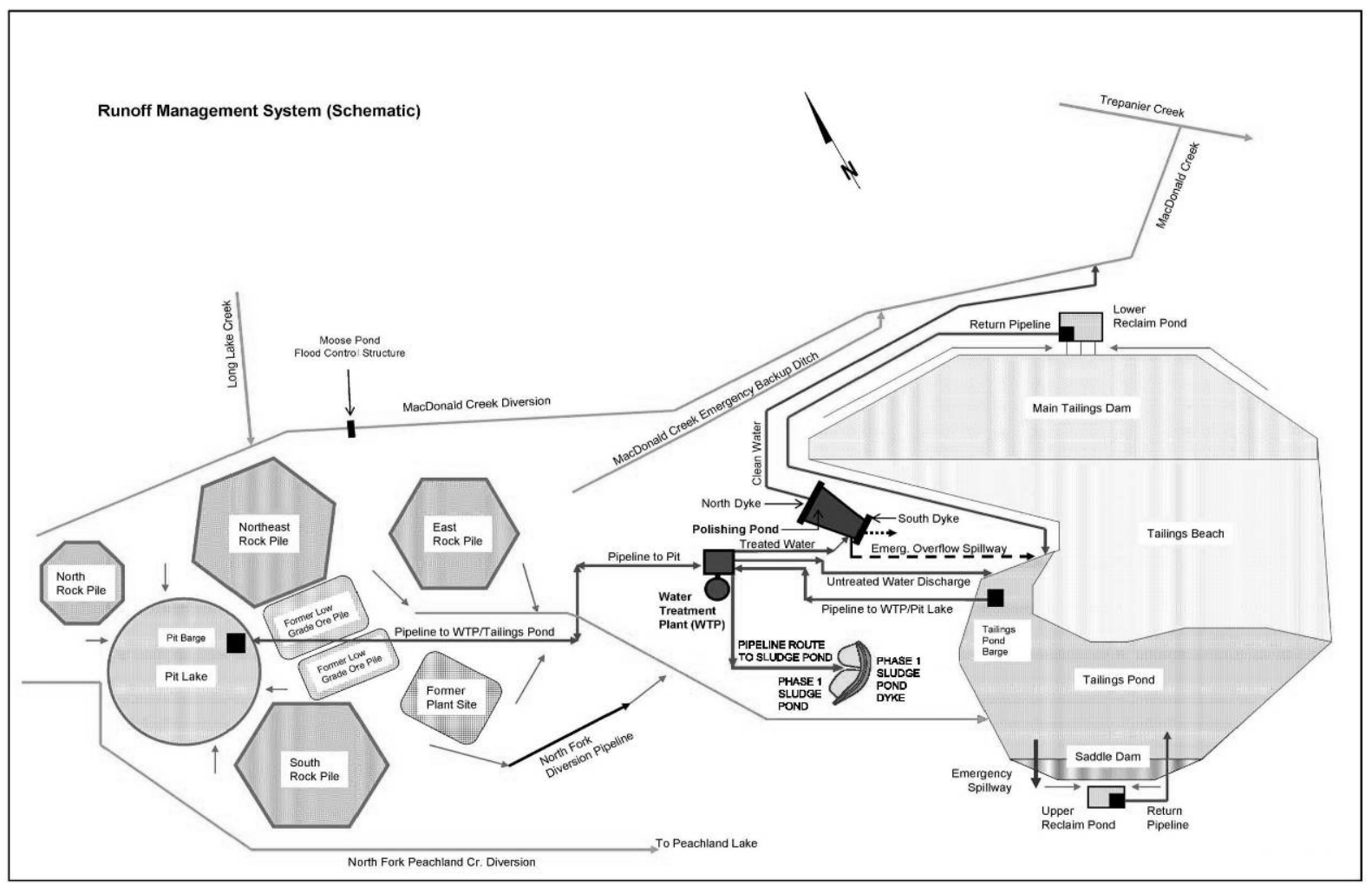

Figure 5 Mine site runoff management scheme (Agra, 1998a)

Key features of the runoff management scheme are the following:

- Divert clean water around the mine site to downstream creeks (Figures 6a and 6b).

- Collect molybdenum-bearing water in the tailings pond and pit lake.

- Treat water collected in the tailings pond and/or pit lake in the water treatment plant and store it in the polishing pond.

- Release treated water from the polishing pond to MacDonald Creek under permit.

- Store sludge from the treatment plant in the permanent sludge pond.

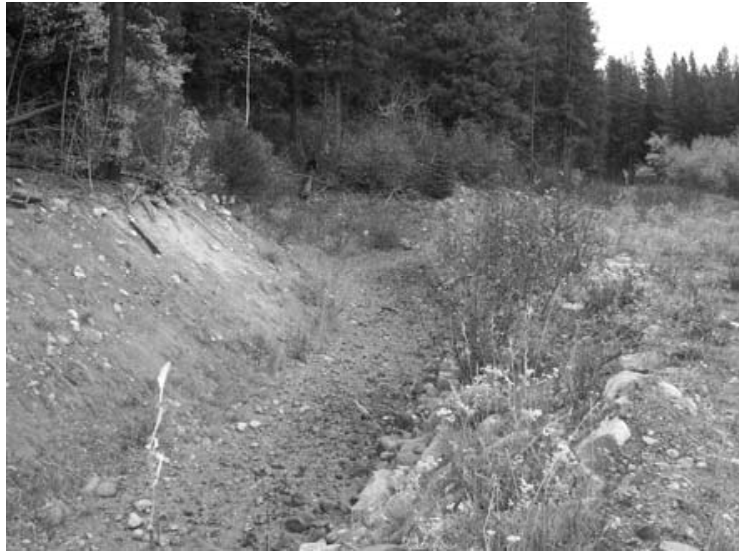

(a)

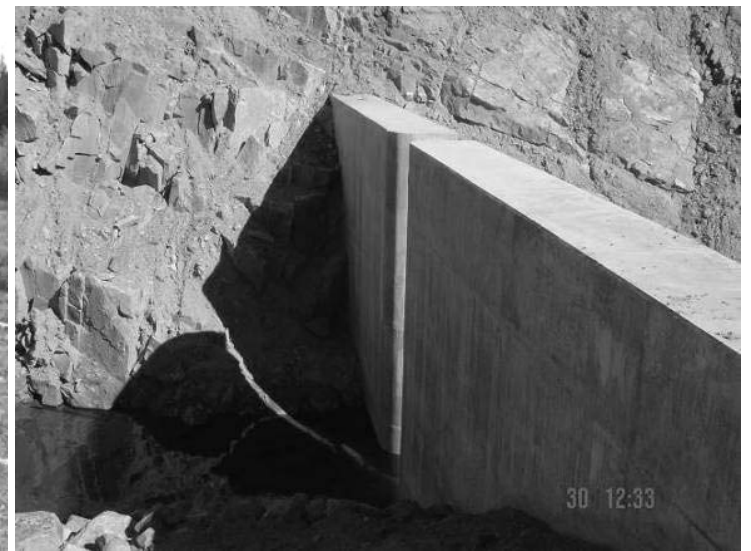

(b)

Figure 6 (a) MacDonald Creek diversion channel; and (b) Moose Pond flow-control concrete weir used to attenuate flood flow to tailings pond 
Annual site water balances are calculated based on actual operation flows, meteorological and hydrological records. A review of the site water balances by Amec (2003), formerly Agra, confirmed the 1998 simulated water balance used for the runoff management design.

\section{$4 \quad$ Water treatment operation}

In 1998, a water treatment plant (Aubé and Stroiazzo, 2000) with a maximum installed treatment capacity of 313 litres was constructed and started operation. Mine site water stored in the tailings pond and pit lake has been treated in the water treatment plant and released on a scheduled annual basis under permit. Ongoing monitoring of surface and groundwater quality at control locations has also been carried out. Key elements for the water treatment operation include:

- Water treatment plant.

- Polishing pond.

- Permanent sludge pond.

\subsection{Water treatment plant}

The primary concern in Brenda's tailings pond and waste rock drainage is molybdenum at a concentration of approximately $3 \mathrm{mg} / \mathrm{l}$. The mine drainage is alkaline and contains little or none of the typically problematic heavy metals. Given that the water downstream is used for municipal water supply and some irrigation, a discharge limit of $0.25 \mathrm{mg} / 1$ molybdenum was imposed with specific water quality guidelines $(\mathrm{Mo}<0.03 \mathrm{mg} / \mathrm{l})$ in the receiving creek (BCEMPR, 2002; BCMELP 2003). A review of all existing and potential molybdenum removal methods was undertaken prior to mine closure. The chosen process is a twostep iron co-precipitation with clarification and sand filtration at a slightly acidic $\mathrm{pH}$ value. A $912 \mathrm{~m}^{3} / \mathrm{hr}$ (4,000 Usgpm) treatment plant was constructed and commissioned in 1998, at a cost of $\$ 10.5$ million (Figures 7 and 8 ). Sludge was initially stored in temporary ponds until 2001, when the permanent sludge pond was constructed.

The Brenda water treatment plant has successfully treated molybdenum from site drainage since start-up in October 1998. Among the lessons learned are:

- Iron co-precipitation combined with sand filtration can consistently bring molybdenum concentrations in the receiving creek to less than $0.03 \mathrm{mg} / \mathrm{l}$.

- Low concentrations of iron $(<0.2 \mathrm{mg} / \mathrm{l})$ in the plant effluent can be treated with lime prior to discharge into the polishing pond. If caustic is used alone for neutralisation of the effluent water, settling of the minuscule precipitates may be difficult. The calcium from lime apparently acts as a coagulant to enhance the settling properties of iron hydroxides.

- The sludge formed from the process is essentially stable when exposed to atmospheric conditions, such as in the permanent sludge pond with a sand filter for enhanced draining. 


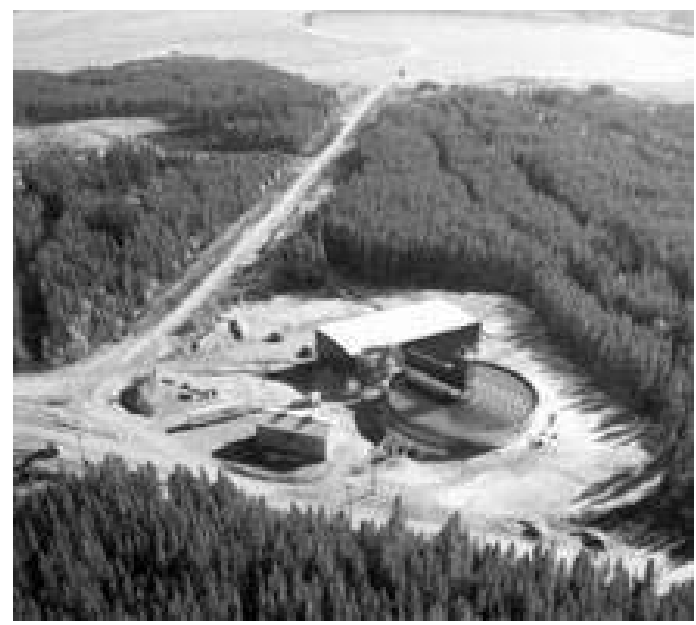

Figure 7 Water treatment plant

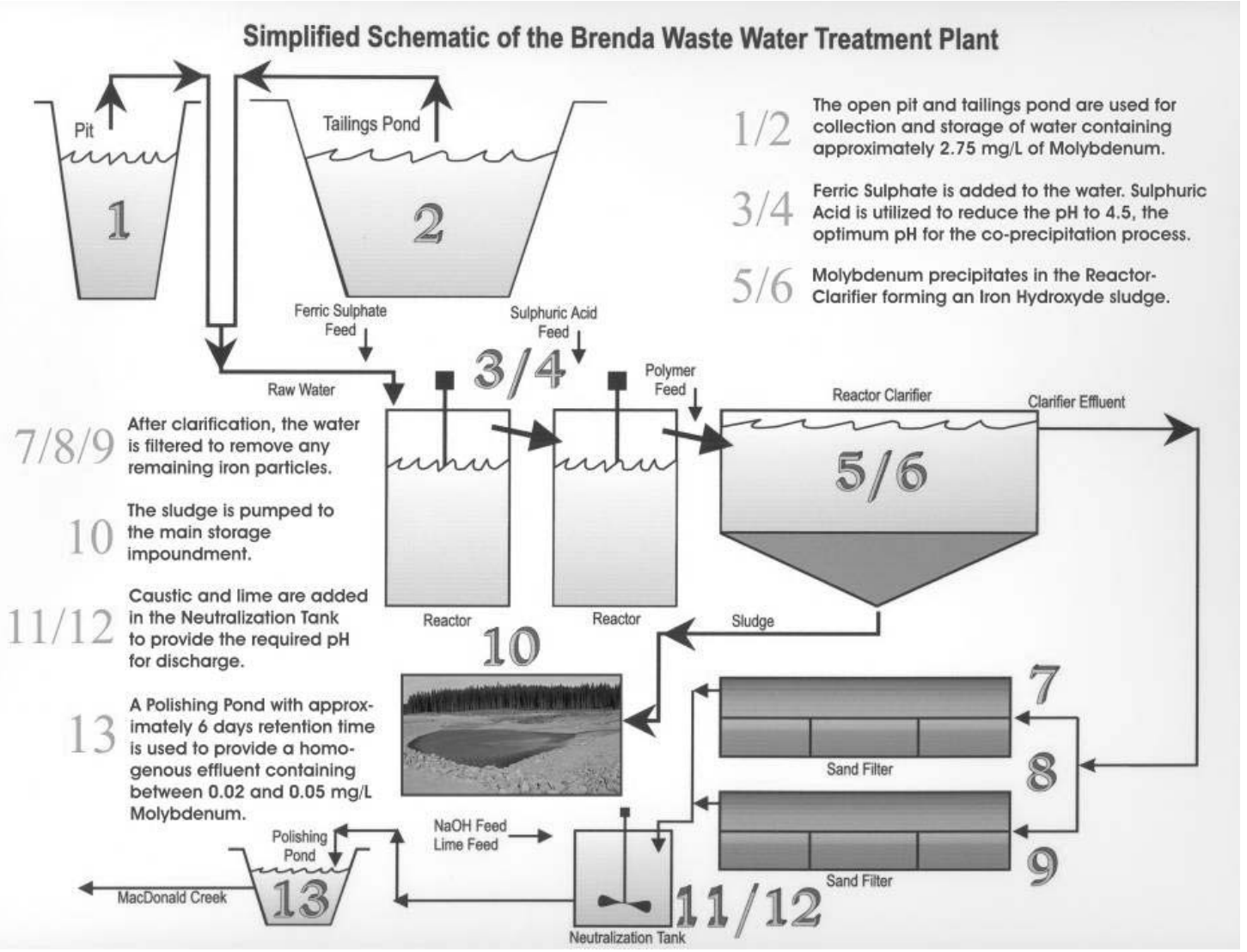

Figure 8 Schematic diagram of water treatment process

\subsection{Seasonal release of treated water and water-quality monitoring}

The release of treated water during the months of May to October (Figure 11b) are following a detailed permit (BCMELP, 2003) with specified water-quality characteristics of the discharge as well as waterquality objectives at the downstream irrigation intake works. The maximum allowed rate of discharge is 6 million $\mathrm{m}^{3} / \mathrm{yr}$ with an anticipated average rate of 3.1 million $\mathrm{m}^{3} / \mathrm{yr}$. The permit also governs mine site management of sludge. Besides ongoing reporting to the ministry, Brenda has also published newsletters each year reporting the progress of water treatment plant operation and Trepanier Creek water quality monitoring data to inform the public (Figure 9). 

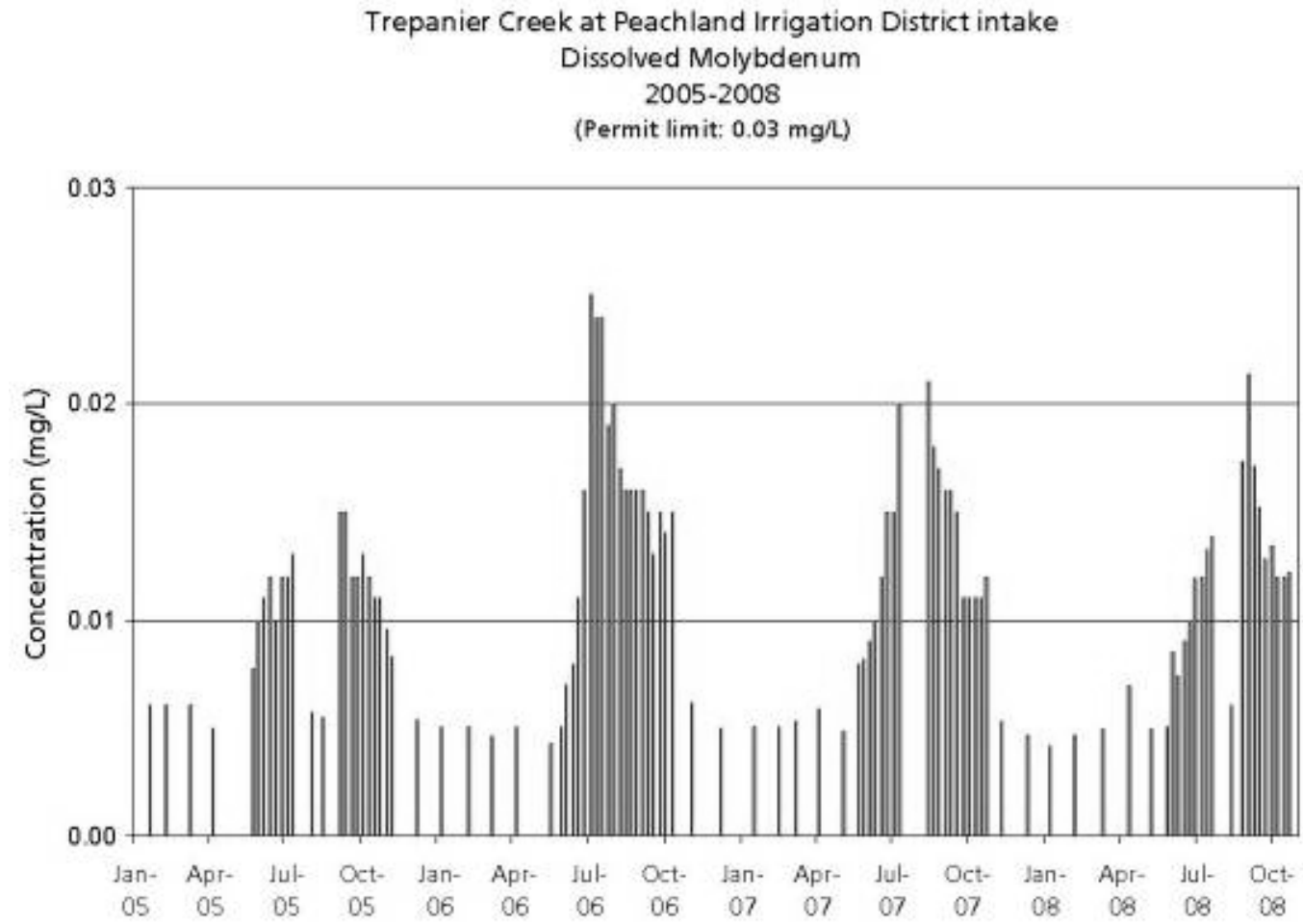

Trepanier Creek at Peachland Irrigation District intake Dissolved Sulphate 2005-2008

(Permit limit: $250 \mathrm{mg} /$ )

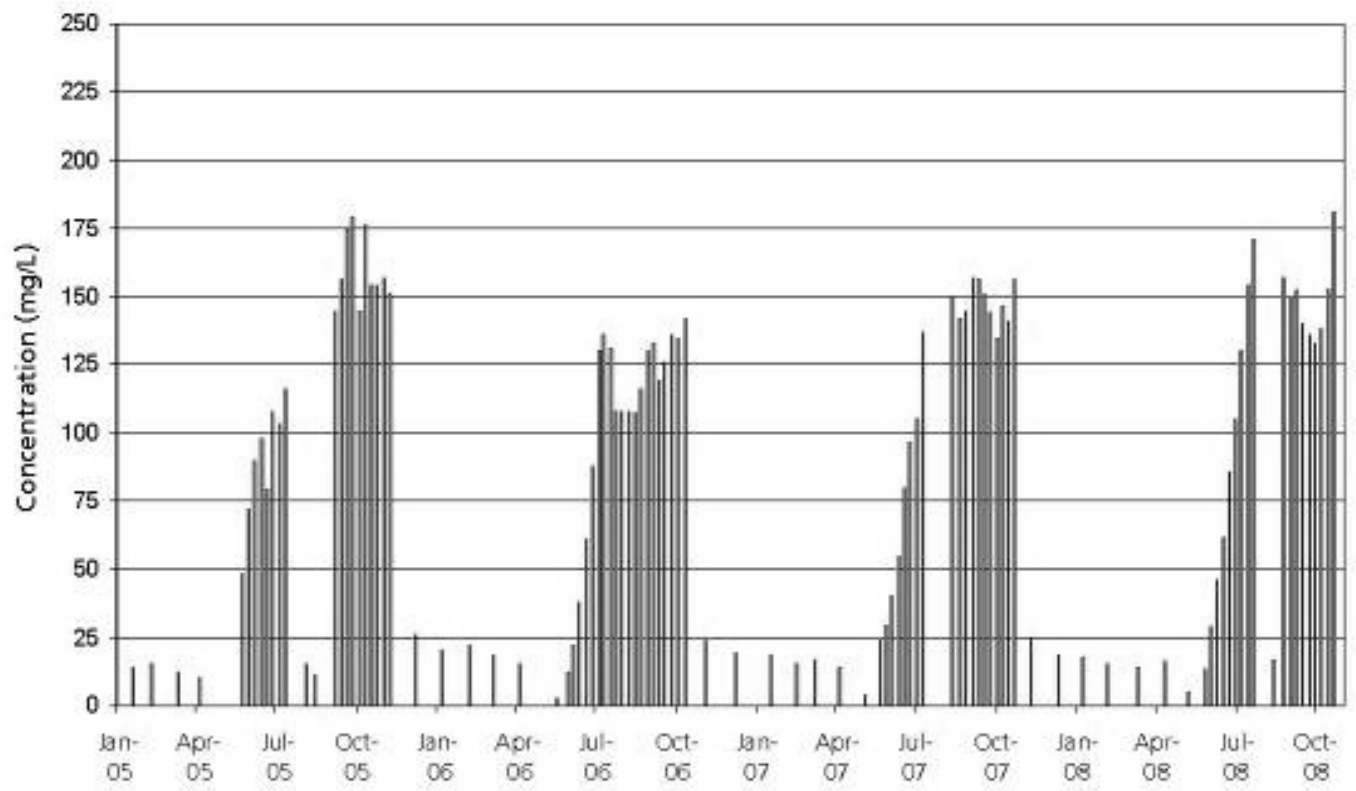

Figure 9 Dissolved molybdenum (top) and sulphate (bottom) in Trepanier Creek at Peachland Irrigation District Intake (2005-2008)

\subsection{Polishing pond}

The polishing pond is located in a natural swale between the water treatment plant and the tailings impoundment (Figure 5). The pond is retained by two earthfill dykes of similar design: the $8 \mathrm{~m}$ high north dyke (Figure 10a) and $4 \mathrm{~m}$ high south dyke (Figure 10b). The dykes were designed by Agra, and constructed in 1998 (Agra, 1998b). Both dykes were essentially constructed of relatively impervious glacial till with a central cutoff trench and an upstream riprap slope protection zone overlying a filter layer. The cutoff 
trenches were backfilled with glacial till to tie in with the dense glacial till and bedrock foundation. A horizontal sand and gravel drainage blanket was provided at the base of the downstream shell in the north dyke, but not at the south dyke. A $45 \mathrm{~cm}$ diameter Sclair underflow drain pipe was installed through the foundation of the south dyke for the purpose of draining the polishing pond to the tailings pond in case of an upset in the water treatment system. A spillway is located at the east abutment of the south dyke.

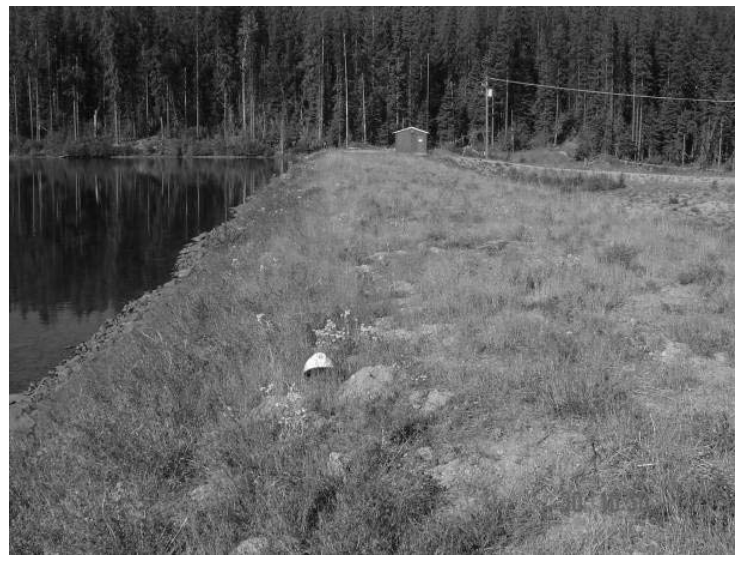

(a)

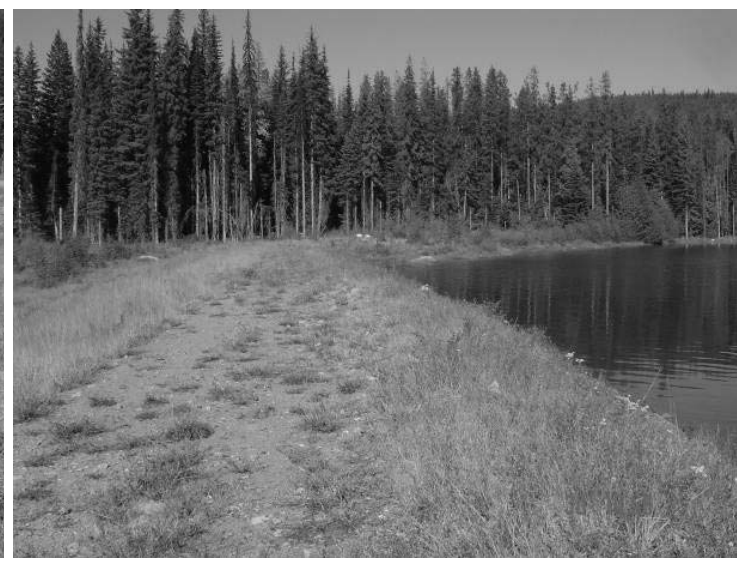

(b)

Figure 10 (a) Polishing pond - north dyke and (b) south dyke

\subsection{Permanent sludge pond}

The sludge storage facility was constructed in 2001, and its design was covered in Amec (2002). The water treatment plant was expected to generate sludge containing approximately $40 \%$ iron and $5 \%$ molybdenum. The sludge dyke could be raised in the downstream direction in stages to provide additional storage volume. The amount of actual sludge generated, after it has dewatered, dried and consolidated, has been on average, less than $400 \mathrm{~m}^{3} /$ year.

The permanent sludge pond is located about $600 \mathrm{~m}$ southeast of the water treatment plant on sloping ground, above the tailings impoundment (Figure 5). The sludge pond is retained by a crescent-shaped dyke constructed of pervious earth and rockfill materials (Figure 11a). The sludge dyke was constructed on stripped competent, water-tight ablation till foundation overlying dense basal till and coarse felsic intrusive bedrock. Two multi-level monitoring wells, BH\#1 (three piezometers) and BH\#2 (two piezometers), were installed, respectively, downstream and upstream of the sludge pond to monitor groundwater levels and quality. Downward groundwater gradient and seasonal variation were observed in both monitoring wells to date. At the deep piezometer in downstream well, BH\#1, the piezometric level rose by about $1 \mathrm{~m}$ from 2002 to 2003 and stayed at similar levels since then. No other consistent piezometric changes could be discerned. From 2003 to 2009, water quality of groundwater remained unchanged at the upstream well, BH\#2. At the downstream well, BH\#1, dissolved molybdenum maintained at 0.001 to $0.005 \mathrm{mg} / \mathrm{l}$ level, while dissolved sulphate increased from 20 to $30 \mathrm{mg} / \mathrm{l}$ level to 200 to $400 \mathrm{mg} / \mathrm{l}$ level.

The $6.5 \mathrm{~m}$ wide crest of the retaining dyke for the sludge pond is at El. 1,399.8 $\mathrm{m}$. The invert elevation of the emergency spillway, located at the northwest abutment of the sludge dyke is at El. 1,398.9 m. The dyke consists of a trapezoidal-shaped fine rockfill section overlying a $0.5 \mathrm{~m}$ thick sand and gravel base blanket. Upstream of the fine rockfill zone are three zones in consecutive upstream order: a $0.6 \mathrm{~m}$ thick sand and gravel layer, a $0.3 \mathrm{~m}$ thick sand filter and a $0.4 \mathrm{~m}$ thick riprap zone. The pervious dyke is designed to facilitate the ongoing draining and consolidation of the sludge deposits. 

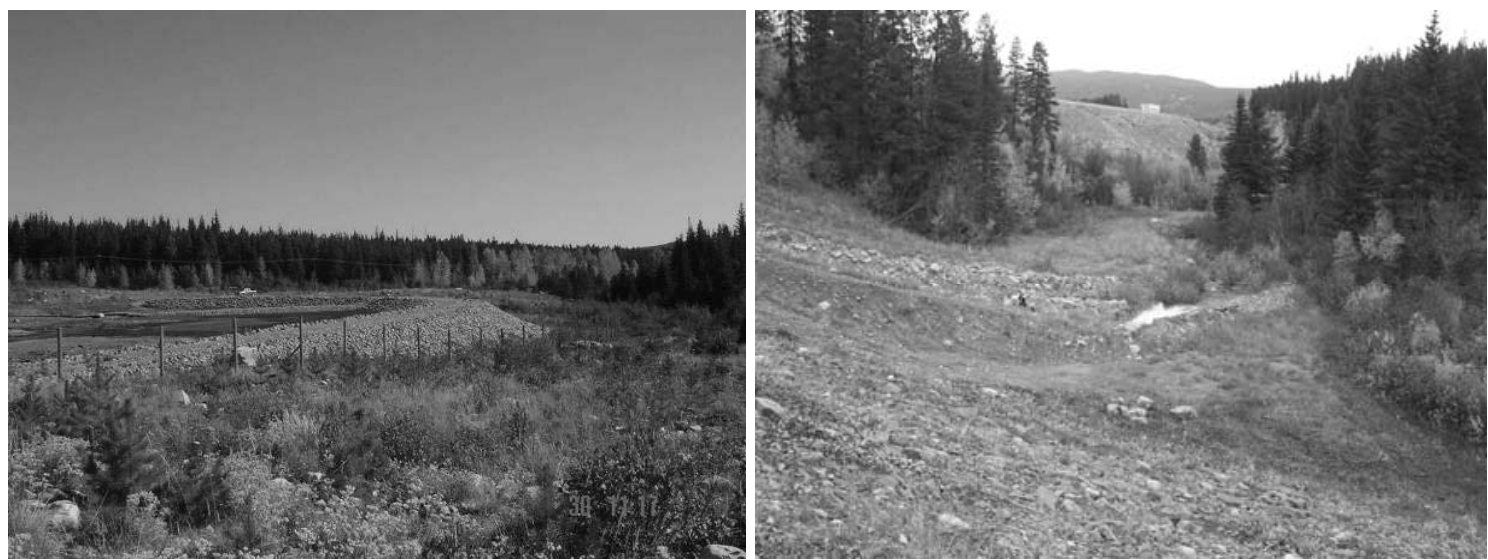

Figure 11 (a) Permanent sludge pond retained by a crescent-shaped sludge dyke and (b) release of treated water through a pipeline from the polishing pond to MacDonald Creek

\section{$5 \quad$ Site care and maintenance}

The site care and maintenance work is carried out by two permanent staff and one part-time worker. Automatic remote communication system is set up to assist the staff to monitor the site over 24 hours a day and seven days a week. Besides operating the water treatment plant from May to October, the staff also carry out site care and maintenance work for the three impoundments. Outlined below are these activities and the status of the open pit and waste rock piles and former low-grade ore piles.

\subsection{Site impoundments}

Physical surveillance of all dams and dykes in the following impoundments are carried out regularly by Brenda staff. In addition, the dams and dykes are reviewed annually and a comprehensive dam safety review is conducted every decade by a geotechnical consultant.

\subsubsection{Tailings impoundment}

Tailings impoundment, including main and saddle dams, tailings pond, lower and upper reclaim dams, lower and upper reclaim ponds, pumping systems for tailings pond water reclaim, and seepage water reclaims.

The tailings pond level is operated closely within a targeted range between 1,382.5 and 1,385 $\mathrm{m}$. The lower reclaim pond is maintained in a range between a sump level at $2.74 \mathrm{~m}$ in the summer $(2.62 \mathrm{~m}$ in the winter) and $2.44 \mathrm{~m}$, while the upper reclaim pump is typically operated only for a few weeks in the spring. The minimum operating freeboard is $6 \mathrm{~m}$ for the former, and $7 \mathrm{~m}$ for the latter. In addition, the former has an open-crest spillway with an invert located $1.5 \mathrm{~m}$ below the dam crest, while the latter has a culvert spillway with its invert located about $1 \mathrm{~m}$ below the dam crest.

Piezometers installed within the main dam and saddle dam and in the foundation of the main dam and the lower reclaim dam as well as discharges from the main dam finger drains are monitored regularly.

\subsubsection{Polishing pond}

Polishing pond, including the north and south dykes, outlet structure for treated water, and polishing pond.

The polishing pond is normally operated with the outlet control structure fully open during discharge, such that the pond level is maintained just above elevation $1405.35 \mathrm{~m}$. Since 2007, the pond level is maintained within a relatively high optimal range with an automatic level sensing and control device to minimise stirring up of iron deposits and their subsequent entrainment in the effluent.

\subsubsection{Permanent sludge pond}

Permanent sludge pond, including the sludge dyke, sludge transfer system, leachate collection system, and sludge solids. 
The permanent sludge pond is sub-divided into two cells with a divider dyke, and sludge is stored into alternate cells each year. The sludge pipeline is discharged into the pond at least $25 \mathrm{~m}$ from the sludge dyke, and a minimum freeboard of $0.9 \mathrm{~m}$ is maintained at all times.

Sludge depth, seepage discharge, quality of pond water and groundwater in two multi-level monitoring wells are regularly monitored, more frequent during sludge discharge season.

\subsection{Open pit}

The open pit, shown in the top of both photos in Figure 12, is located at the upper most part of the Brenda property, with the following physical characteristics: diameter $914 \mathrm{~m}$, perimeter $5 \mathrm{~km}$; depth (from rim) $335 \mathrm{~m}$ at the west end and $240 \mathrm{~m}$ at the east end. The volume of pit-lake water is typically about 34 million $\mathrm{m}^{3}$. Figure 12 also shows the conditions of the mine and mill site during mining operation and after removal of mining related structures for decommissioning. Figure 14a shows the pit lake with a pump barge viewed through a safety fence.
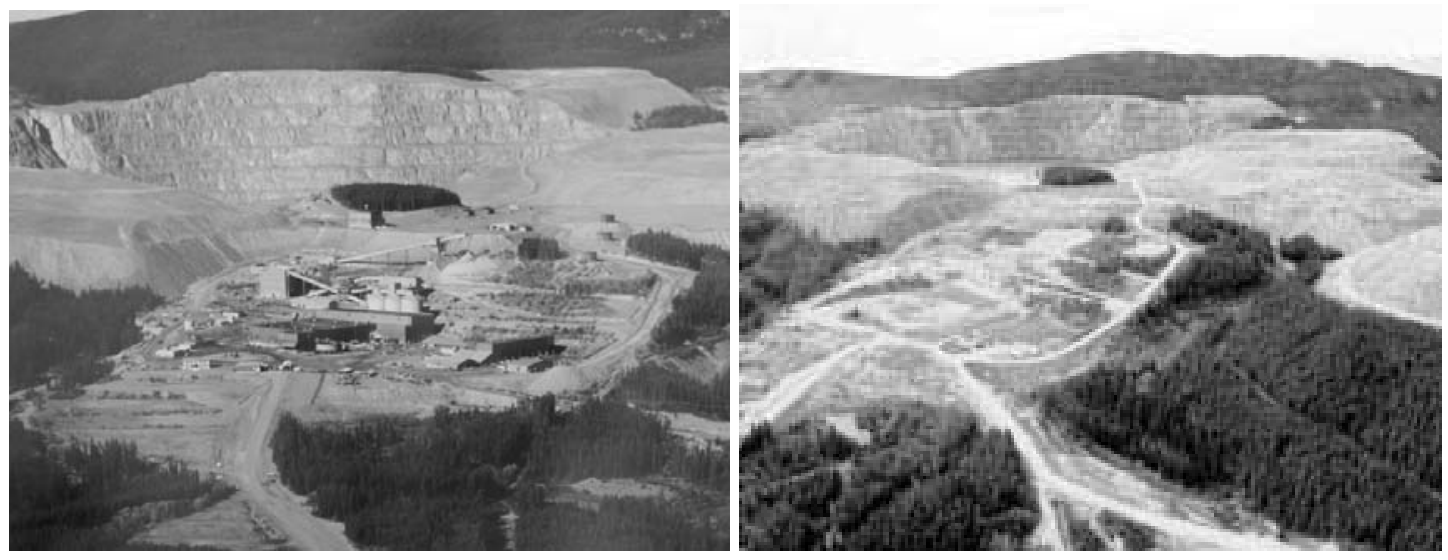

Figure 12 Mine and mill site during mine operation and after decommissioning

The mining operation ceased at Brenda in June 1999 after a sudden failure of the west pit wall on 9 April 1990, which shut down the mine prematurely by about five months. Since then, the pit has been in-filled with natural drainage around the pit, groundwater recovery and water pumped from the tailings pond. Golder (1998) reviewed the long-term pit slope stability and concluded that there is a low potential for a rapid failure of instability zones on the north and west walls with a slide volume in the order of 2 million $\mathrm{m}^{3}$. To mitigate the possibility of large waves being generated in the pit lake by any future pit-wall slide, the lake level is maintained below El. $1512 \mathrm{~m}$ by treating and releasing excess water accumulated within the pit lake. In addition, the pit walls are monitored by a series of monitoring pins positioned on the north and west walls.

Results of steady-state groundwater flow analyses using a groundwater modelling indicated the presence of a local groundwater recharge zone around the pit lake. There is little likelihood of seepage losses from the pit lake towards the east low pit wall, as long as the lake level stays below the original ground surface around the pit wall at approximately El. $1521 \mathrm{~m}$. Twenty groundwater monitoring wells were installed in 1986 and 1998 around the low wall side of the open pit for ongoing monitoring and confirming the water quality of groundwater in the vicinity of the pit lake (Klohn Crippen, 1998). Results of the dissolved molybdenum and sulphate levels monitored in the 1986 series wells from 1996 to 2000 are shown in Figure 13 (Amec, 2001). These results indicate that practically no changes to groundwater chemistry have occurred since 1996. 
Molybdenum Levels in Series '86-pit' Piezometers

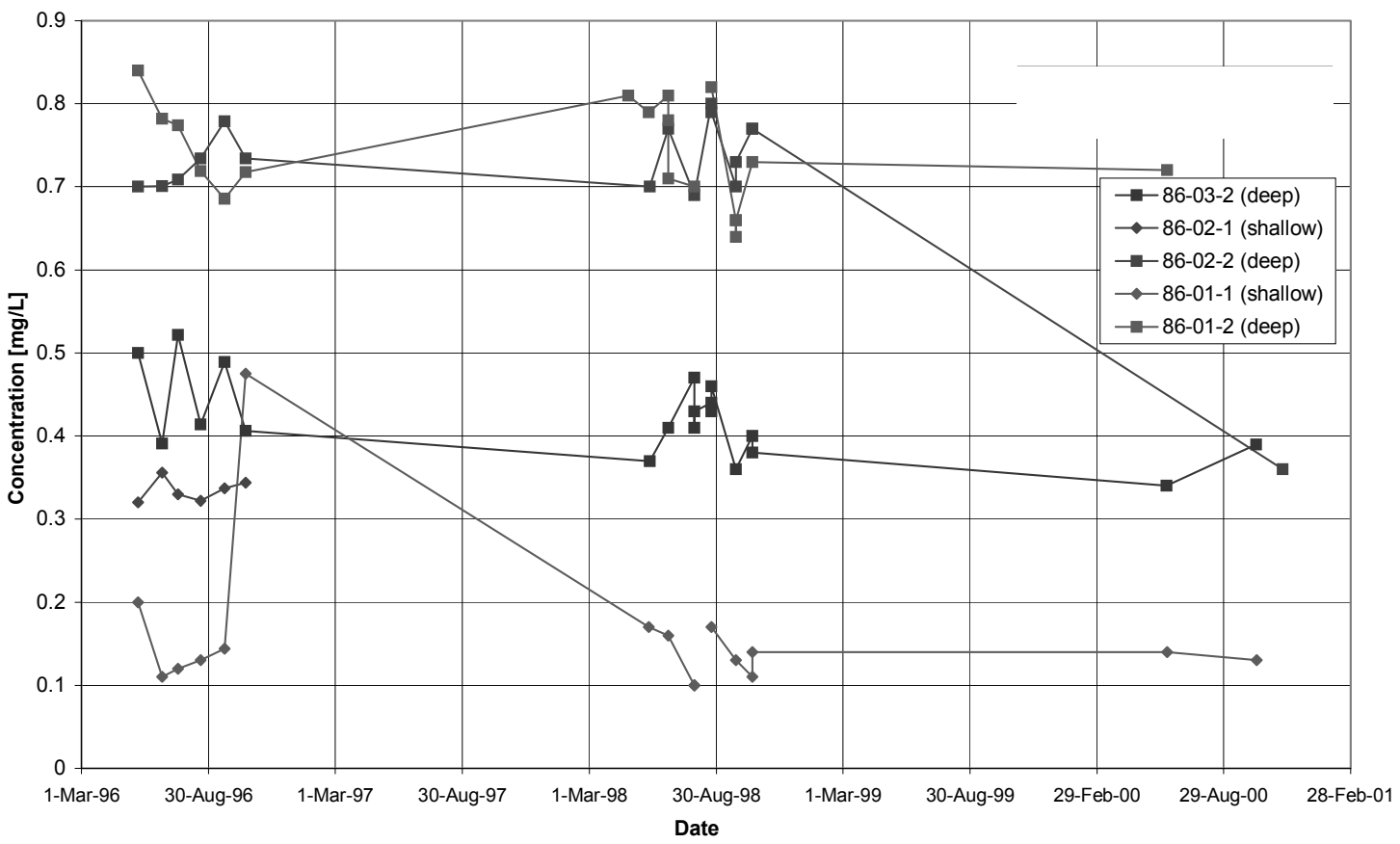

Sulphate Levels in Series '86-pit' Piezometers

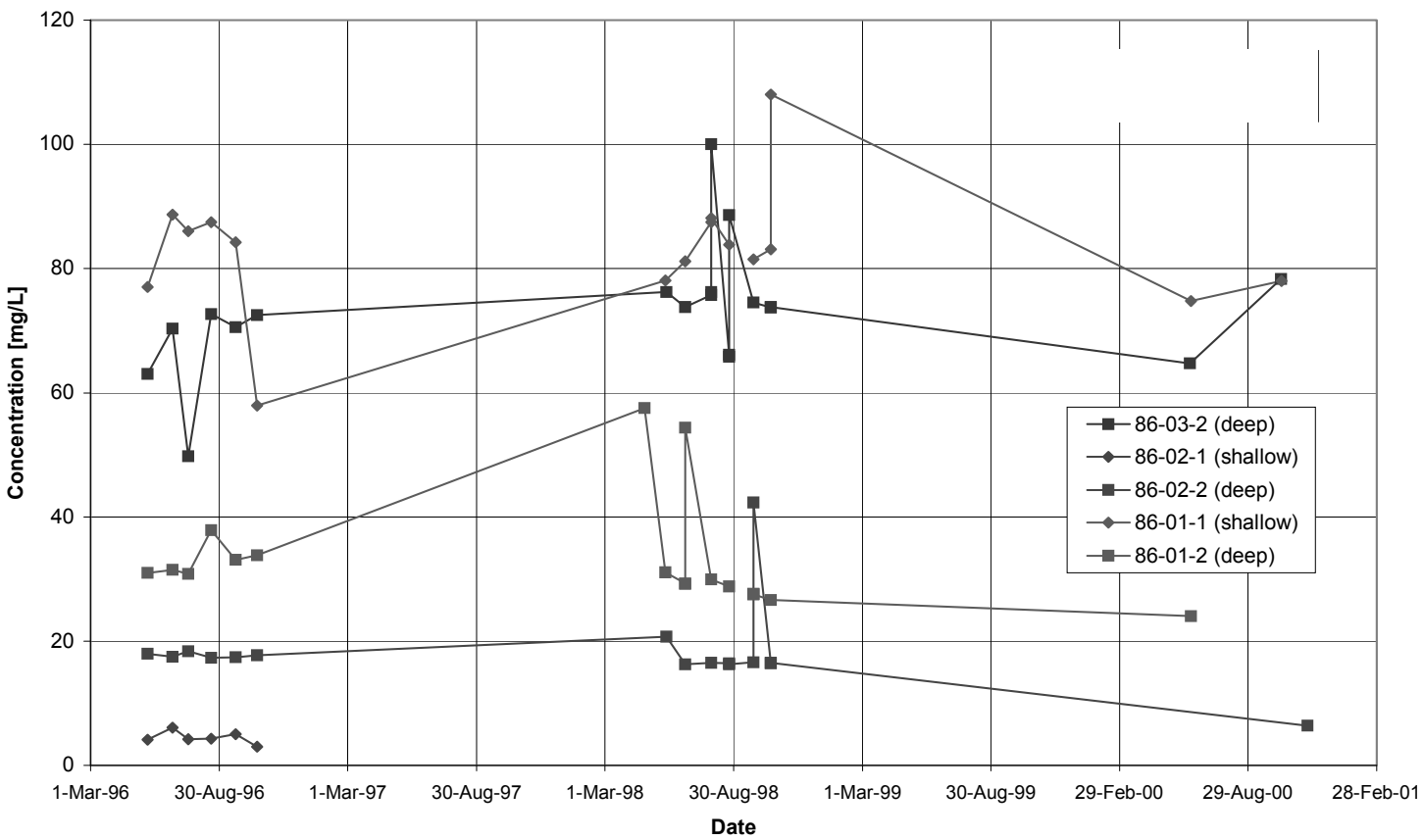

Figure 13 Dissolved molybdenum (top) and sulphate (bottom) levels in 1986 series multi-level monitoring wells (1996-2000). Note that the interpolation between data points is neither necessary for the purpose of this evaluation, nor intended 


\subsection{Waste rock piles and former low-grade ore piles}

There are four waste rock piles and two smaller former low-grade ore piles around the open pit:

- North rock pile - 8.1 Mt of waste rock occupying an area of 18 ha with a maximum height of $89 \mathrm{~m}$.

- Northeast rock pile -54.3 Mt of waste rock occupying an area of 27 ha with a maximum height of $63 \mathrm{~m}$.

- East rock pile - 25.5 Mt of waste rock occupying an area of 28 ha with a maximum height of $99 \mathrm{~m}$.

- South rock pile - 21.2 Mt of waste rock occupying an area of 40 ha with a maximum height of $117 \mathrm{~m}$. Figure 14b shows the view of the northeast slope of the south rock pile.

Contaminated site drainages through the waste rock piles and low-grade ore piles are collected in the pit lake and tailings pond.
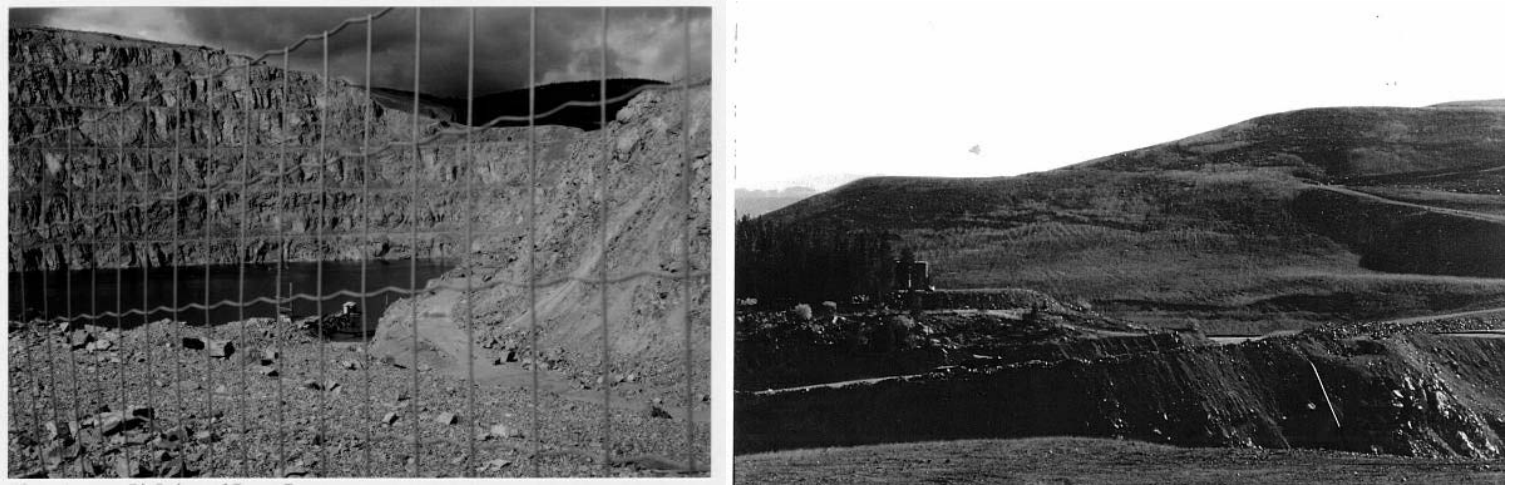

Figure 14 (a) Pit lake with pump barge; and (b) northeast slope of south waste rock pile

The waste-piles competent foundation consists of a thin mantle of dense to very dense glacial till overlying fresh diorite/granodiorite bedrock. These waste rock piles have been re-graded, flattened and seeded where the pile is not confined by drainage courses, tree stands or access roads. Only where the south pile adjoins the active southwest pit wall slide in the open pit is there indication of ongoing slow movement towards the pit. All other waste rock piles have been stable from their initial construction to date.

On 18 September 2007, a sudden gush of about $59,000 \mathrm{~m}^{3}$ of water issued from the east waste rock pile toe for about one day. It flooded the access road and discharged into the tailings pond. The incident was investigated by Amec (2007). The source of water was considered to be melted snow incorporated in the rock pile. Its sudden release was probably due to the thaw and breach of a frozen seepage barrier within the rock pile. No significant deformation of the waste rock pile was observed in the incident. It is possible for similar incidents to occur in other rock piles. However, the resulting melt water is expected to flow into the pit lake and/or tailings pond.

\subsection{Reclamation and vegetation control}

Reclamation work at the mine was carried out whenever practical during mining operation. Ongoing reclamation continues to date.

\subsubsection{Reclamation}

Re-vegetation of inactive areas disturbed during operation of the Brenda Mine is effectively completed. The last major re-contouring and seeding effort was completed in 2003 with seeding and fertilising of 5.5 ha on the mill site platform. With virtually no new land disturbance occurring at the mine site, no major additional revegetation is anticipated. Maintenance fertilising continues in certain re-vegetated areas. Spring fertilising of the tailings dam face and crest is done annually (approximately $75 \mathrm{ha}$ ). The tailings beach is fertilised every five years (approximately 150 ha last fertilised in 2005). Scheduling may be revised upon vegetation assessments. 


\subsubsection{Vegetation control}

Control of vegetation in active operating areas is an important facet of mine site maintenance. Vegetation control programmes are primarily defined based on routine monitoring and surveillance, with brush clearing campaigns typically required every two or three years in a given location. Removal of fallen trees or trees posing a potential hazard is done on a more frequent, as required basis.

\section{Acknowledgements}

The authors would like to express their appreciation to the management of the Xstrata Copper for permitting the publication of this paper. Moreover, Brenda Mine owes its success in ongoing mining and decommissioning operations over the past four decades, to the continuous dedication of its staff and consultants. The contribution of these numerous individuals is acknowledged collectively herein.

\section{References}

Agra Earth and Environmental Ltd (Agra) (1999) Brenda Mine Closure Project - Saddle Dam - Emergency Discharge Structure, Internal report (unpublished).

Agra Earth and Environmental Ltd (Agra) (1998a) Brenda Mine Closure - Long Term Runoff Management System Design, Internal report (unpublished).

Agra Earth and Environmental Ltd (Agra) (1998b) Polishing Pond - As-Built Report, Internal report (unpublished).

Amec (2007) Inspection of the Flooding Event from the East Rock Pile, Internal report (unpublished).

Amec (2003) Brenda 2003 Hydrologic Model, Internal report (unpublished).

Amec (2002) Brenda Mines - Phase 1 Sludge Disposal Facility - Detailed Design, Internal report (unpublished).

Amec (2001) Brenda Pit Area - Review of Groundwater Monitoring Results, Internal report (unpublished).

Aubé, B.C. and Stroiazzo, J. (2000) Molybdenum Treatment at Brenda Mines, Proc. of 5th International Conference on Acid Rock Drainage, Society for Mining, Metallurgy, and Exploration (SME), Denver, Colorado.

British Columbia Ministry of Environment Lands and Parks (BCMELP) (2003) Permit PE-00263 (last amended on May 27, 2003), British Columbia Ministry of Environment Lands and Parks (now Ministry of Environment).

British Columbia Ministry of Energy, Mines and Petroleum Resources (BCEMPR) (2002) Permit M-12 (last amended on May 10, 2002), British Columbia Ministry of Energy, Mines and Petroleum Resources.

Golder Associates Ltd (1998) Review of Long-term Pit Slope Stability, Internal report (unpublished).

Klohn Crippen Consultants Ltd (1998) Open Pit Hydrogeology, Internal report (unpublished).

Klohn, E.J. (1984) The Brenda Mines' Cycloned-Sand Tailings Dam, Proc. of 1st International Conference on Case Histories in Geotechnical Engineering, May, pp. 953-977.

Stanley Associates Engineering Ltd (Stanley) (1995) Water Management Master Plan for the Brenda Mine Site, Internal report (unpublished).

Steffen Robertson and Kirsten (Canada) Inc. (SRK) (1992) Mathematical Modelling of Molybdenum Leaching from the Brenda Mine Rock Piles, Internal report (unpublished).

Steffen Robertson and Kirsten (Canada) Inc. (SRK), Rescan Environmental Services Ltd, C.E. Jones and Associates Ltd and H.M. Larratt Aquatic Consulting Ltd (1993) Brenda Mine Decommissioning Plan, Internal report (unpublished). 